This document was prepared in conjunction with work accomplished under Contract No. DE-AC09-96SR18500 with the U. S. Department of Energy.

\title{
DISCLAIMER
}

This report was prepared as an account of work sponsored by an agency of the United States Government. Neither the United States Government nor any agency thereof, nor any of their employees, makes any warranty, express or implied, or assumes any legal liability or responsibility for the accuracy, completeness, or usefulness of any information, apparatus, product or process disclosed, or represents that its use would not infringe privately owned rights. Reference herein to any specific commercial product, process or service by trade name, trademark, manufacturer, or otherwise does not necessarily constitute or imply its endorsement, recommendation, or favoring by the United States Government or any agency thereof. The views and opinions of authors expressed herein do not necessarily state or reflect those of the United States Government or any agency thereof.

This report has been reproduced directly from the best available copy.

Available for sale to the public, in paper, from: U.S. Department of Commerce, National Technical Information Service, 5285 Port Royal Road, Springfield, VA 22161, phone: (800) 553-6847, fax: (703) 605-6900

email: orders@ntis.fedworld.gov

online ordering: http://www.ntis.gov/help/index.asp

Available electronically at http://www.osti.gov/bridge

Available for a processing fee to U.S. Department of Energy and its contractors, in paper, from: U.S. Department of Energy, Office of Scientific and Technical Information, P.O. Box 62, Oak Ridge, TN 37831-0062,

phone: (865)576-8401,

fax: (865)576-5728

email: $\underline{\text { reports@ adonis.osti.gov }}$ 
WSRC-MS-2003-00140

\section{Design Competition \\ for DeVelopment of a General Purpose Fissile Package}

\author{
T. K Houghtaling \\ G. A. Abramczyk \\ D. S. Hoang \\ D. R. Leduc \\ R. N. Lutz \\ R. W. Watkins \\ T. Wu
}
A. C. Smith
P. S. Blanton
J. L. England
L. F. Gelder
N. K. Gupta
E. T. Ketusky
C. A. Mckeel

J. S. Bellamy
Westinghouse Savannah River Co.

\begin{abstract}
In general, the design process involves envisioning and developing concepts for a component or system, combining these fractions into an integrated whole and evaluating the final design against functional requirements. A major challenge is developing components or systems to a level of maturity that permits feasibility evaluation of the integrated whole while optimizing opposing performance functions (e.g., thick for strength, but thin for heat transfer). Economic pressure often drives design concepts to conservative bases early in the process. The approach presented in this paper is a highly costeffective means of developing alternative design solutions for given set of design requirements - in this case a radioactive materials (RAM) transportation package.
\end{abstract}

In response to planned phase-out of the Department of Transportation (DOT) 6M specification package, an internal competition was held at the Savannah River Site to develop design proposals for the $6 \mathrm{M}$ replacement. Two teams were provided with design requirements, design evaluation criteria, a limited budget and short time frame to develop proposals for a General Purpose Fissile Package (GPFP). Resulting GPFP designs, while quite different, met the performance requirements, were economical, operator friendly, light weight, certifiable, and able to accommodate a wide range of radioactive materials. The methodology of an in-house design competition proved to be a very cost effective way of advancing design alternatives from design requirements to practical design proposals. Estimated fabrication costs for each of the designs are significantly less than other packages currently available for the proposed service.

\section{Background}

Department of Transportation (DOT) 6M specification packages have been used extensively for transportation of radioactive materials since the 1960 's. However, since the $6 \mathrm{M}$ specification was issued, the state of the art of radioactive materials packaging has advanced significantly. In addition, the existing fleet of $6 \mathrm{M}$ packages is aging and is marked by significant variability in quality. Because of this, the DOT has instituted a phased elimination of the $6 \mathrm{M}$ specification package (and others) in favor of packages certified to meet federal performance requirements. Hence, an inexpensive replacement for the $6 \mathrm{M}$ is needed ASAP to avoid unnecessary purchase of significantly more expensive packages needed to support evolving DOE missions.

In response to the DOT action, the Department of Energy (DOE) has initiated a project to design and certify a new, general purpose fissile package (GPFP) to replace the DOT $6 \mathrm{M}$. DOE solicited feedback from $6 \mathrm{M}$ users throughout the DOE complex, addressing radioactive materials (RAM), types and sizes of RAM-handling containers, expected numbers of packages needed for assigned missions, and usability preferences.

\section{Project Objective \& Design Competition}

The objective of the SRS internal design competition was to advance the development of a new performance-based and compliance-certifiable package as a candidate for replacement of the obsolescent DOT $6 \mathrm{M} / 6 \mathrm{~L}$ specification package. The candidate package must meet the intent of the proposed NRC and DOT rulemaking for a low cost, user friendly, single containment, general-purpose fissile material package -- the GPFP.

Toward that end, the SRS Radioactive Materials Packaging Technology (RMPT) staff and personnel from supporting organizations were divided into two teams, provided with a small budgetary allowance, completion date and charged with the task of developing design proposals for the GPFP. The design proposals would be evaluated by an independent team of judges from the DOE packaging community. Ultimately, a 
future SRS proposal for the GPFP would draw from the concepts developed by each of the teams and from feedback provided by interested members of the DOE packaging community.

\section{Package Requirements}

Requirements the design must satisfy, along with evaluation criteria for judging the competition were developed in discussion with members of the DOE packaging community. The following functional requirements must be met.

\section{- Achieve the DOE's Vision for the GPFP-1 Package}

Develop a safe, efficient, cost-effective replacement for the DOT 6M/6L (30- 55-gallon) specification packaging.

- Incorporate single containment vessel.

- Optimize containment vessel inside diameter for fissile materials. (Reference contents to include plutonium and/or uranium metal and/or oxides per Tables $1.14 \& 1.15$ of 9975 SARP, and Table 5 of 49 CFR 173.417.)

- Promote minimal worker exposure via ease of use.

\section{- Meet All Regulatory Requirements.}

Include sequential Crush Test as part of NRC 2002 Rulemaking (NRC/IAEA alignment).

- Enable the package to carry more than $1000 \mathrm{~A}_{2}$ units of radioactive material.

- Implement ASME Section III.

- Satisfy NNSA Service Expectations

Deliver certifiable, defensible design features.

- Apply established technology to facilitate certification.

- Ensure minimum 20 year service life.

- Minimize maintenance.

- Avoid degradable insulation.

- Ensure compatibility with current cargo restraint transport (CRT) system used in Safe Secure Trailers (SSTs).

- Document evaluation per Regulatory Guide 7.9

\section{Design Competition Evaluation Criteria}

Many individuals within the DOE packaging community were asked to provide suggestions for evaluation criteria and criteria weighting. The final basis for judging the competition was a 100 point scoring system weighted as follows.

1) Utility (40 points)

- Enhanced packaging capability: Consider RAM species, form, mass and presence of contaminants, particularly carbon, beryllium and other $(\alpha, n)$ reactors. Adapt as much as possible from the 9975/SAFKEG authorization bases.

- Optimal number of packages shippable per conveyance: Consider both weight and radiological issues. Optimize overpack size and shape to support optimal use by the NNSA Office of Secure Transportation (OST).
2) Cost (20 points)

- Fabrication cost in lots of 100: Desired unit cost is less than $\$ 3000$ per packaging.

- Life cycle costs: Include maintenance, parts replacement and recertification effort.

3) Ease of Use (20 points)

- Efficiency of assembly: Include exposure time and difficulty of operations. Avoid exotic tooling. Minimize pre-use inspections of components.

- Ease of satisfying maintenance and testing requirements: Make parts interchangeable to the extent possible.

- Stackability: Provide for storage of empty packagings or compatibility with inexpensive pallet stacking.

- Minimal content justification and preparation

4) Performance (10 points)

- Ease of certification: Include use of proven, tested, defensible technologies and certified components.

- Margin of safety relative to performance requirements

5) Development Cost and Schedule (10 points)

\section{Team Activities}

Two teams, self-named Magenta and Gold, developed design concepts and preformed scoping assessments to demonstrate their feasibility. Each team reviewed a wide range of new materials and forms to identify arrangements that would enable the package to meet both regulatory test requirements and user functionality requirements, while minimizing both cost and weight.

Each team carried out scoping analyses to confirm that the design configurations and materials selected would satisfy the functional requirements. To help stay within budget, each team capitalized independently on analytical models available from the extensive history of drum package development sponsored by DOE. Hence, the teams only needed to alter the model(s) selected sufficiently to evaluate candidate design concepts.

\section{Two Different Concepts}

In general, most RAM transportation packages consist of a containment vessel $(\mathrm{CV})$ and an overpack that protects the $\mathrm{CV}$ from structural and thermal intrusions. Both design teams pursued established radioactive materials packaging technology, but altered some features to minimize fabrication cost and to improve operability.

\section{$\underline{\text { Containment Vessel and Closure }}$}

Both teams utilized proven design features for their respective CVs that have been parts of previously certified packages. However, significant differences arose between the two team's design proposals for $\mathrm{CV}$ configurations. 
Magenta chose to incorporate into their design a well established Chalfant CV (from the certified 9975 package) without significant modification and to focus their efforts on other aspects of the package. The Magenta $\mathrm{CV}$ is sized to accommodate a $1 / 2$-inch walled payload basket for incorporation of gamma or neutron shielding materials (as the basket itself) or perhaps hydrogen gettering materials, see Figure M1.

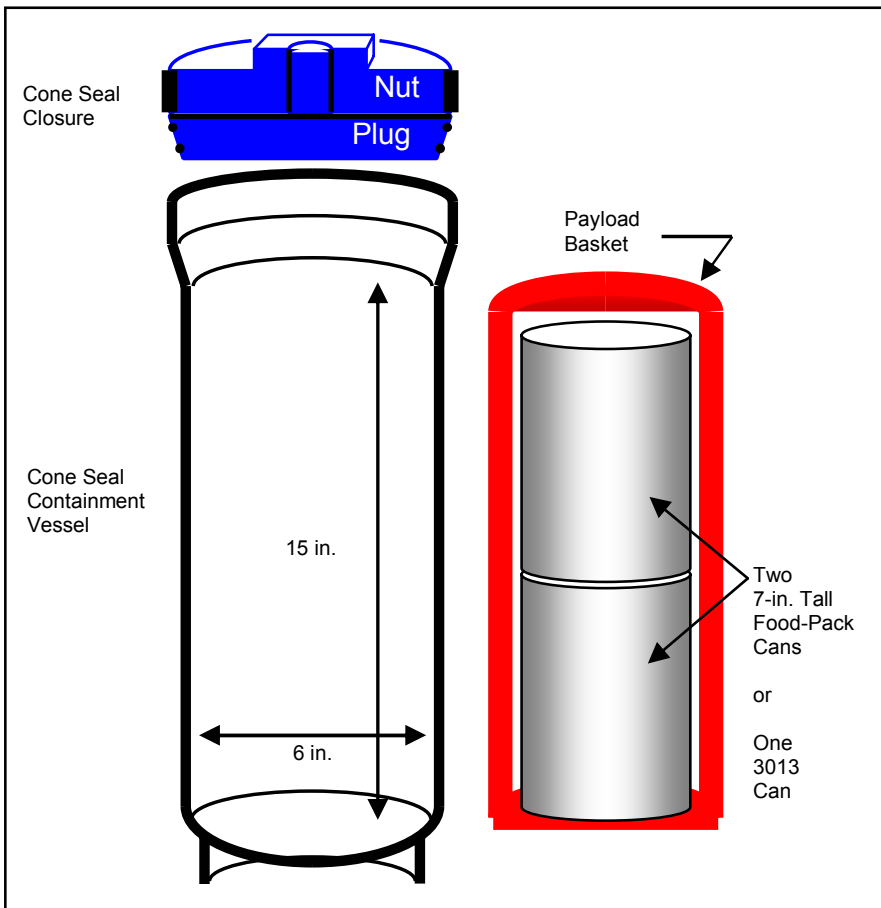

Figure M1 - Magenta Cone-Seal CV and Payload in Basket

Gold chose to develop a somewhat heavier but significantly lower-cost version of the Chalfant CV. The lower cost variation retained the exceptionally effective conical closure seal of the Chalfant design, but replaced the more costly twopiece tapered plug and threaded retainer (so-called "nut") with a simpler single-piece plug secured by a circle of bolts, see Figure G1.

\section{Overpack and Closure}

An overpack commonly consists of impact and thermal protection sandwiched between inner and outer shells. Both teams selected rigid polyurethane foam as the basic source of impact and thermal protection, but differed in their implementations and in their overpack closure designs.

Magenta selected two poured-in-place installations of mediumdensity foam within a nearly standard 35-gallon stainless steel drum, see Figure M2.

Magneta's overpack closure lid and drum are sandwiched circumferentially within a close-fitting, U-section flange (inverted). No more than six sets of bolt/nut fasteners are necessary to secure to the closure, see Figure M3.

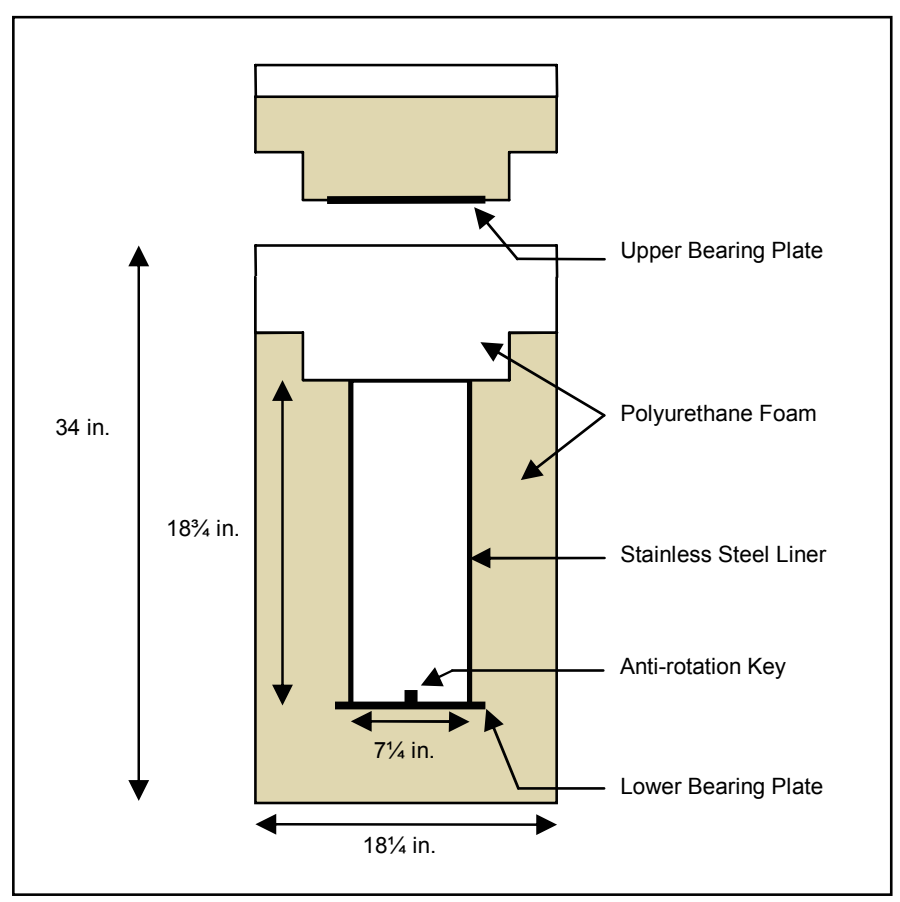

Figure M2 - Magenta 35-gallon Drum Overpack

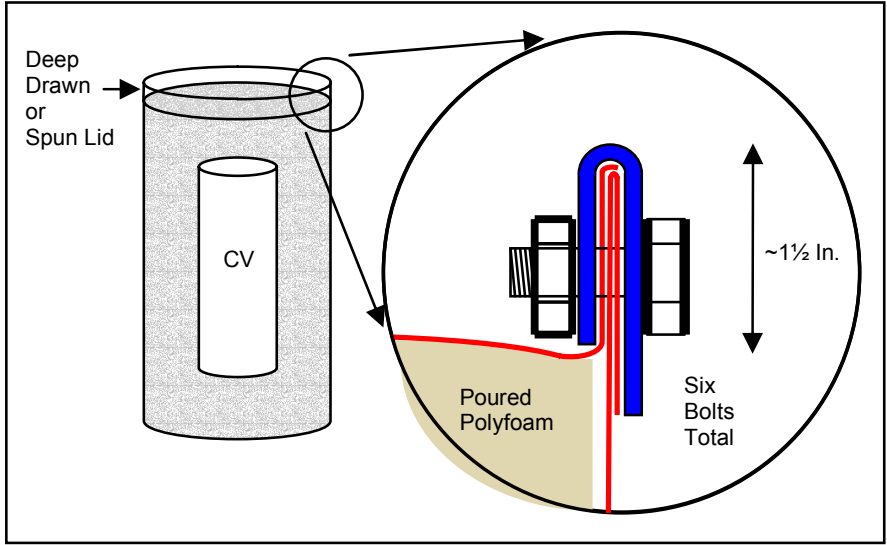

Figure M3 - Magenta Overpack Closure

Gold chose a thick-walled, hollow cylinder of low-density foam surrounding a smaller cylinder of stiffer borated silicone material. The boron within the silicone provided neutron shielding. In addition, aluminum load distribution plates above and below the $\mathrm{CV}$ protect the foam from damage by mishandling of the $\mathrm{CV}$, see Figure G1.

Gold's outer shell is fabricated from a commercial stainless steel closed-head drum. The overpack is consists of two portions such that the entire top third could be removed, exposing the $\mathrm{CV}$ for convenient loading. The top and bottom sections of the shell are joined securely by a self aligning bolt ring, see Figure G1. 


\section{Component Weights}

Magenta packaging components add up to $195 \mathrm{lb}$. The payload basket is credited as part of the payload and does not add to the mass of the packaging (empty package).

Gold packaging components add up to $260 \mathrm{lb}$. Here too, a payload basket could be credited as part of the payload.

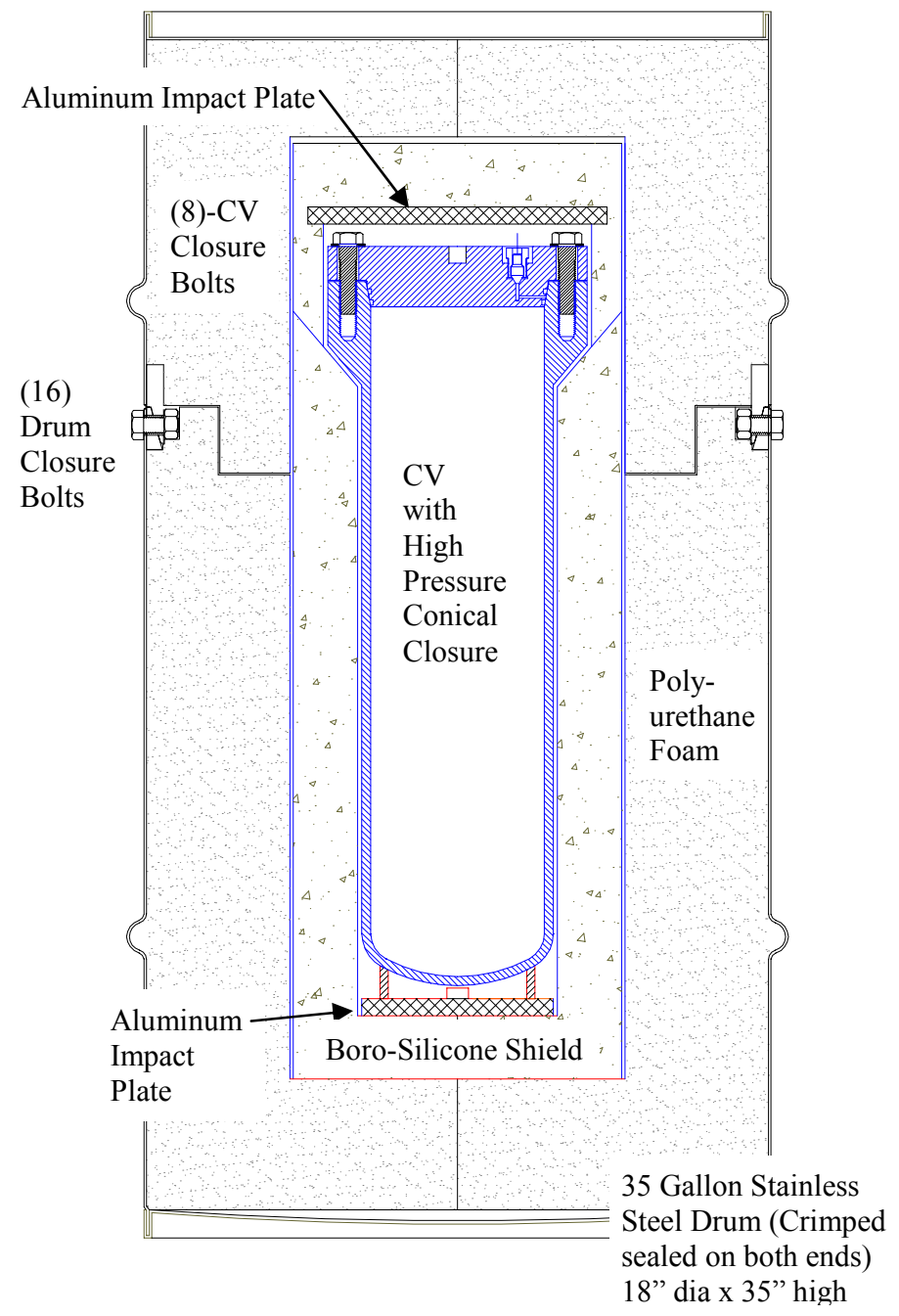

Figure G1 - Gold Design Cross Section

\section{Scoping Analyses}

Scoping analyses were necessary to confirm the ability of the overpack designs to withstand the test sequence of the regulatory hypothetical accident conditions (HAC). This includes both structural and thermal assaults on the package.

Both teams were confident that a polyurethane foam overpack would withstand the nine-meter Free Drop and one-meter Puncture Drop tests. However, for these package designs, the
Crush test imparts roughly four times the impact energy of the Free-Drop test and is very challenging to most drum type packages. $^{[1]}$ Accordingly, each team needed some form of structural calculation to assess the ability of the proposed polyurethane foam material (alone or in combination with other structural components) to withstand the Crush test.

In addition to the impact evaluation, Gold's fresh CV design necessitated evaluation of its pressure capability to ensure consistency with the Chalfant (9975) vessel.

After a prototype package has been through the drop/puncture/crush tests, it is subjected to 30 minutes of engulfing flames. Hence, each team needed some form of thermal calculation to assess the ability of the proposed overpack to protect the portion of the $\mathrm{CV}$ most sensitive to heat -- its elastomeric seals.

\section{Structural Analyses}

Gold's analysis of pressure retaining capability confirmed that their new CV design would provide performance comparable to the Chalfant configuration. An example of the results from axisymmetric finite element analysis is given in Figure G2. The figure shows that the limiting stress would occur in the vessel wall rather than in the $\mathrm{CV}$ closure components.

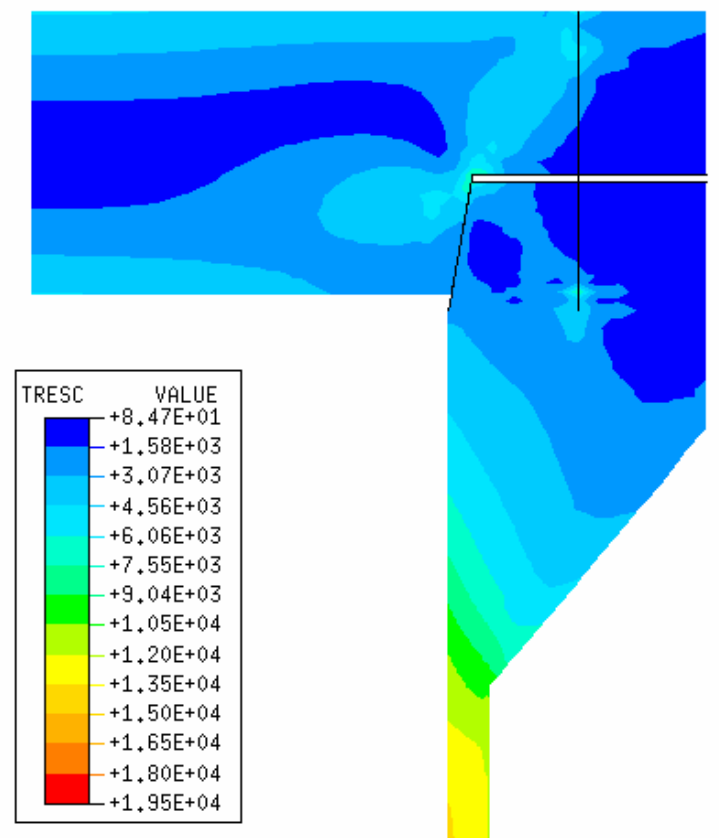

Figure G2 - Contour Plots of Maximum Stress Intensity at 8,400 lb. Total Bolt Pre-Load and at Pre-load Plus 1200 psi Internal Pressure

Each team carried out structural analyses of the overpack designs under regulatory Crush-test loading. Gold chose 2-D analysis of the softer mid-section of their design to investigate the ability of their nested-cylinder arrangement of polyurethane 
foam plus silicone to protect the CV from loss of integrity. The geometry of the Gold overpack analysis is illustrated in Figure G2.

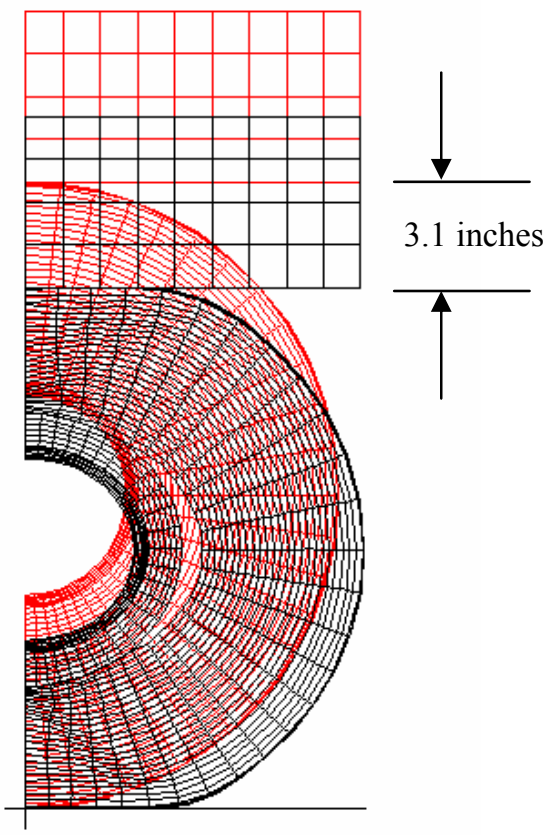

Figure G2 - Gold Overpack Original and Crush-Deflected Shapes

Because Magenta did not need to defend the pressure capacity of their CV design, they were able to focus on 3-D Crush analysis of the whole of their package design in both horizontal and vertical orientations. For comparison to the Gold results, the deformed geometry from the horizontal Crush event is shown in Figure M4.

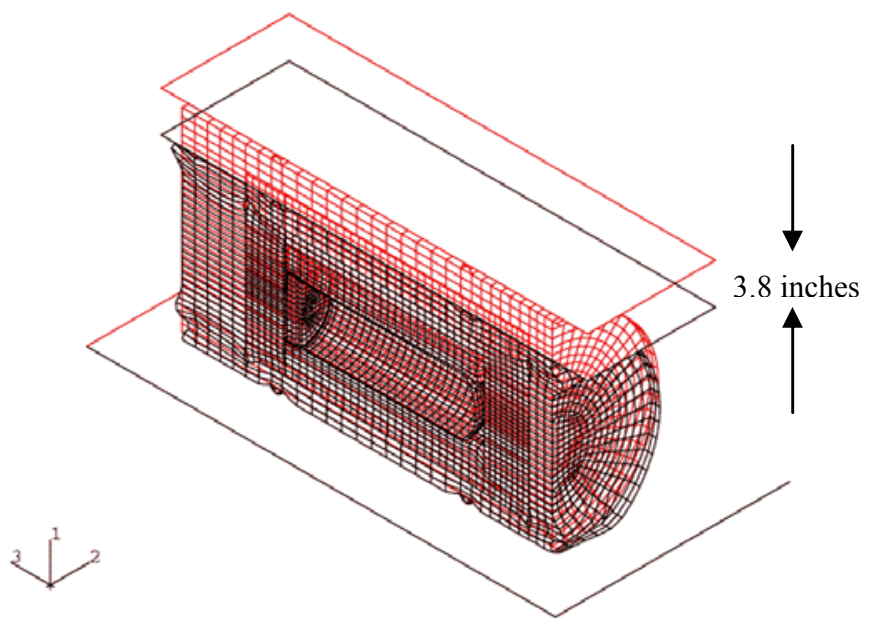

Figure M4 - Magenta Package Original and Crush-Deflected Shapes
Since the CV was part of the 3-D model (adapted from the 9975 model), both stress and plastic strain results were available as shown in Figures M5 and M6.

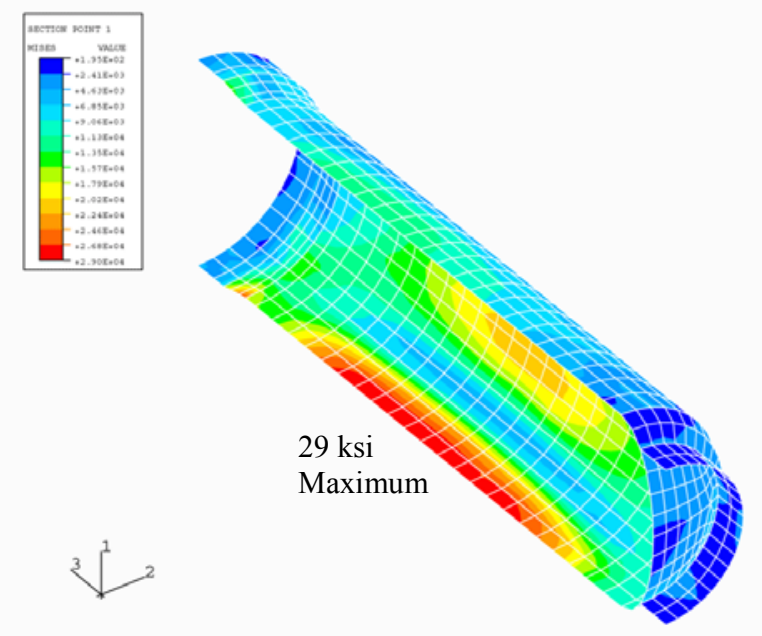

Figure M5 - Magenta CV Horizontal Crush Evaluation Von Mises Stress

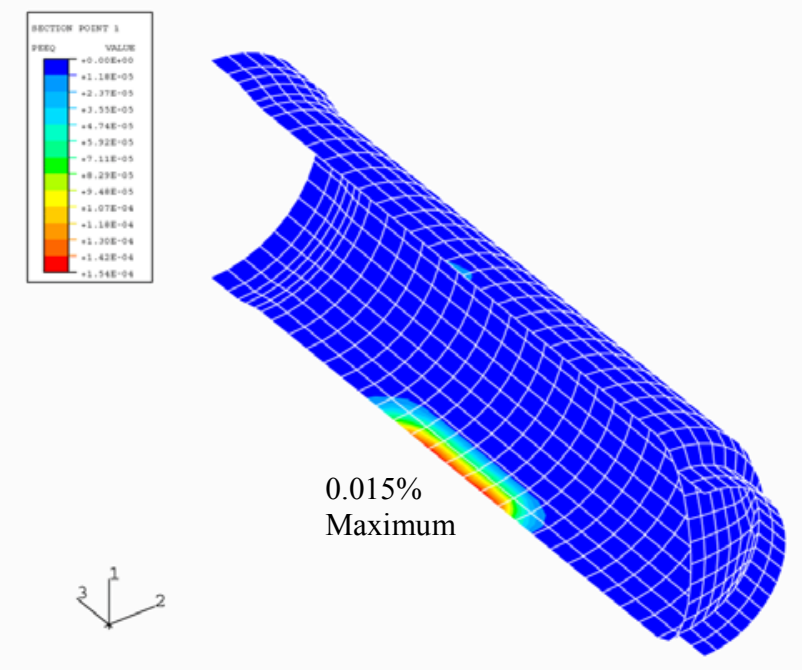

Figure M6 - Magenta CV Horizontal Crush Evaluation Equivalent Plastic Strain

In summary, independent analyses from each of the teams confirmed that an overpack containing rigid polyurethane foam insulation would protect the CV satisfactorily in a regulatory Crush event.

\section{Thermal Analysis}

Thermal calculations examined the ability of the overpack to protect the $\mathrm{CV}$ closure seals and other internal components from the heat of a regulatory Fire event while containing heatgenerating material. Experience with the well-insulated 9975 
package design has shown that temperatures associated with regulatory NCT are bounding for the regulatory Fire event.

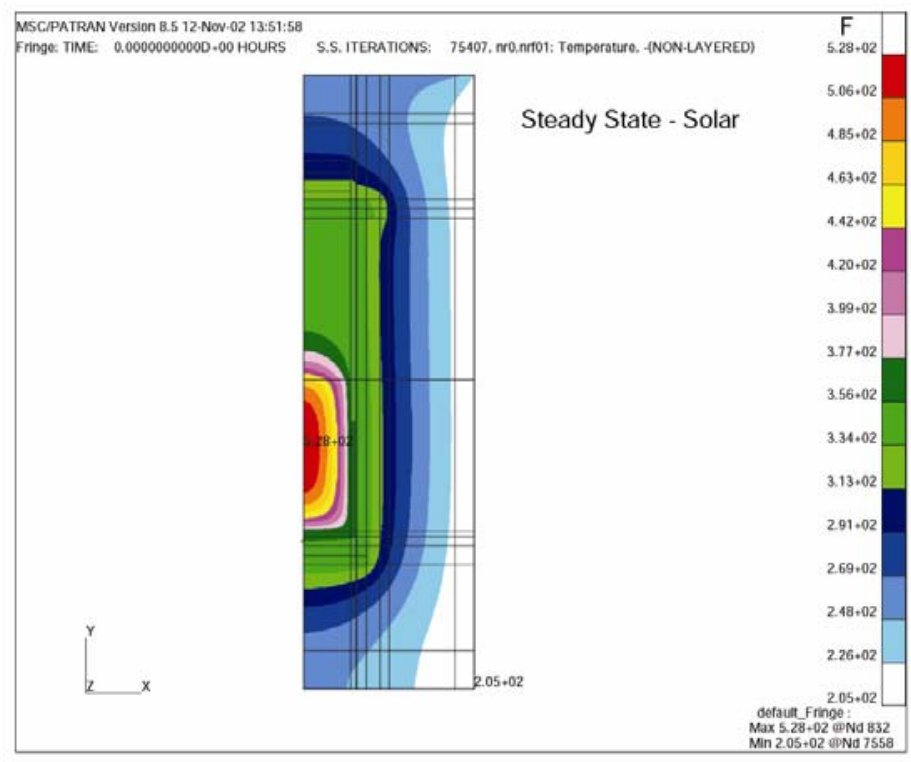

Figure G3 - Temperature Distribution Under Steady State Solar Conditions with 20-Watt Contents

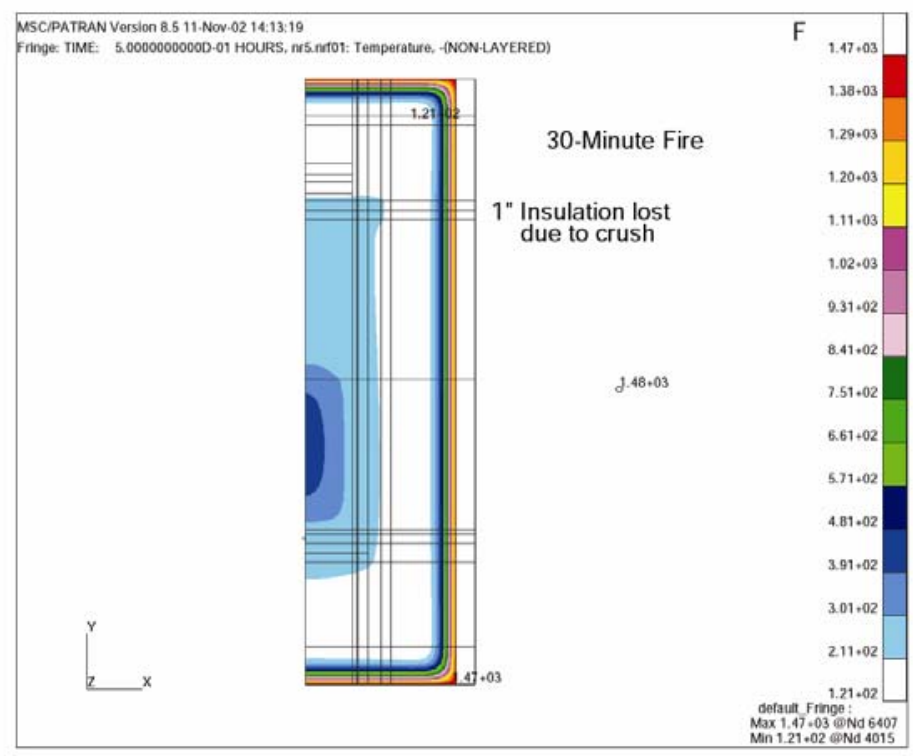

Figure G4 - Peak Temperature Distribution Under Regulatory 30-Minute Fire with 20-Watt Contents

Gold chose to model and analyze two thermal scenarios. These were a steady state solution under continuous solar conditions (more severe than regulatory $\mathrm{NCT}$ ) and a steady state solution without insolation followed by a 30-minute fire transient but without analysis of the post-fire cool-down behavior. The analyses showed that the Gold design can accommodate a
20-Watt payload. Example results from the Gold thermal analyses are given in Figure G3 and Figure G4 as indicative of performance under NCT and for HAC respectively.

Magenta chose not to model thermal behavior via computer but instead to scale this information from existing thermal evaluations of the 9975 package. This low-cost scheme works because the two designs are thermally very similar. However, because of the lower temperature limits necessary to prevent decomposition of the 9975's cane fiberboard insulation, only a lower bound for payload heat could be obtained. Scaled simply from the ratios of insulation conductivities and thicknesses, the lower bound for allowable payload heat within the Magenta design matches the maximum allowed in a $6 \mathrm{M}$ package -10 Watts. However, given the similarity of the Magenta and Gold overpack designs, computer analysis of the Magenta design (incorporating the higher temperature limits of polyurethane) can be expected to increase the allowable payload heat considerably.

\section{Containment}

The Chalfant-design cone seal with double O-rings has been demonstrated to be leak tight. Accordingly, it meets the containment requirements for all materials approved for the 9975 package. (Note that this is contingent upon promulgation of the revision to $10 \mathrm{CFR} 71.63$, eliminating the requirement for double containment of dispersible forms of plutonium.) Both of the proposed $\mathrm{CV}$ designs incorporate a cone-seal closure.

\section{Shielding and Criticality}

In terms of the RAM most commonly transported via $6 \mathrm{M}$ packages, shielding and criticality aspects of the competing GPFP designs are essentially unchanged from the 6M (and from the 9975. The principal form of radiation from the reference fissile contents is $\alpha$-decay and subcritical neutron multiplication from $(\alpha, n)$ reactions. Consequently, for the vast majority of payloads, shielding analysis crediting the $\mathrm{CV}$ and package geometry is sufficient. Both teams proposed optional shielding inserts for payloads needing this feature.

Gold's optional shielding insert (e.g., borated silicone neutron shielding) surrounds the $\mathrm{CV}$, and replaces a portion of the polyurethane foam, see Figure G1.

Magenta's shielding insert is provided in the form a basket that fits inside the $\mathrm{CV}$, thereby minimizing extra weight and providing suitable shielding as part of and specifically for the radioactive payload. Further, if the RAM can be loaded into the basket remotely, the package operator can benefit from the shielding immediately. Located inside the $\mathrm{CV}$, the basket could also incorporate chemical catalysts for gettering hydrogen or recombining hydrogen and oxygen, thereby preventing accumulation of flammable gas mixtures. 
Sub-criticality is insured in $6 \mathrm{M}$ and 9975 packages by limiting the amount and geometry of fissile material in the package. If necessary, either of the shielding schemes proposed by the teams could incorporate neutron poisons, thereby increasing the amount of fissile materials that can be accommodated safely.

\section{Operations}

In addition to proposing economical package designs, each team incorporated enhancements in ease of operation over other popular designs, including the 9975 . Each of the overpack designs provides enhanced operability for the users of the package via removal of one-piece closures.

Gold's new containment vessel can be opened, loaded and closed without the need for special tools and without removal from the overpack. This is accomplished by unbolting and removing the top (roughly $1 / 3$ ) of the overpack. Top removal is a two-man lift, but the effort delivers ample unhindered access to the bolted CV closure, see Figure G1.

Magenta's CV can also be opened while resident within its overpack, but only if the operator is willing to reach down from the top of the drum to access the CV. However, the Magenta $\mathrm{CV}$ is opened/closed via a single bolt, permitting rapid execution of the process. Requiring minimal effort, opening/closing of the Magenta overpack involves only six bolts. Hence, user-friendly operation of the Magenta design minimizes operator exposure to radiation, see Figures M1, M2 and $\mathrm{M} 3$.

\section{Comparison of Design Features}

Each of the GPFP proposals developed in this design competition is economical to fabricate, simple to maintain, user friendly, and capable of accommodating a wide range of fissile and other radioactive contents for safe transportation over public highways.

The heart of every package design is the CV. This device is essential to successful compliance with regulatory performance requirements. Each of the $\mathrm{CV}$ designs provides high-pressure containment performance and structural robustness comparable to the 9975 . The Gold CV is somewhat heavier but should be less costly to fabricate. The Magenta CV is slightly lighter and intended to receive a payload basket. Hence to benefit from inexpensive criticality control, a payload basket must be included as an inside diameter reducer to keep the dimension five inches or less.

Table 1 presents a summary of features from the $6 \mathrm{M}$ specification for comparison with each of the design proposals.
Table 1 - Comparison with 6M

\begin{tabular}{|c|c|c|c|}
\hline $\begin{array}{c}\text { Features } \\
\text { Specs. }\end{array}$ & DOT-6M & $\begin{array}{c}\text { Magenta } \\
\text { Design }\end{array}$ & $\begin{array}{c}\text { Gold } \\
\text { Design }\end{array}$ \\
\hline $\begin{array}{l}\text { Marked } \\
\text { Capacity } \\
\text { (gal) }\end{array}$ & 30 & 35 & 35 \\
\hline $\begin{array}{l}\text { Empty } \\
\text { Weight (lb.) }\end{array}$ & & 195 & 260 \\
\hline $\begin{array}{l}\text { Maximum } \\
\text { Gross Weight } \\
\text { (lb) }\end{array}$ & Up to 480 & 240 & 300 \\
\hline $\begin{array}{l}\text { Packages/ } \\
\text { SST }\end{array}$ & $\begin{array}{c}\text { Soon to be } \\
\text { Zero }\end{array}$ & Up to 50 & Up to 40 \\
\hline $\begin{array}{l}\text { Overpack } \\
\text { Closure }\end{array}$ & $\begin{array}{l}\text { Bolt/Nut } \\
\text { Locking } \\
\text { Ring }\end{array}$ & $\begin{array}{l}\text { Vertical } \\
\text { Flange } \\
\text { (6 Bolts) }\end{array}$ & $\begin{array}{l}\text { Self- } \\
\text { Aligning } \\
\text { Bolt Ring } \\
\text { (16 Bolts) }\end{array}$ \\
\hline $\begin{array}{l}\text { Overpack } \\
\text { Insulation }\end{array}$ & $\begin{array}{l}\text { Cane- } \\
\text { Fiberboard, } \\
\text { Hardwood, } \\
\text { or Plywood }\end{array}$ & $\begin{array}{l}\text { Rigid Poly- } \\
\text { urethane } \\
\text { Foam }\end{array}$ & $\begin{array}{l}\text { Rigid Poly- } \\
\text { urethane } \\
\text { Foam }\end{array}$ \\
\hline $\begin{array}{l}\text { Load Bearing } \\
\text { Plate(s) }\end{array}$ & $\begin{array}{l}\text { Steel or } \\
\text { Wood } \\
\text { Above and } \\
\text { Below } \\
\text { Inner CV }\end{array}$ & $\begin{array}{l}\text { Stainless } \\
\text { Steel }\end{array}$ & Aluminum \\
\hline $\begin{array}{l}\text { Containment } \\
\text { Vessel }\end{array}$ & DOT-2R & $\begin{array}{l}\text { Shorter } 9975 \\
\text { SCV } \\
\text { (Single-Bolt } \\
\text { Closure) }\end{array}$ & $\begin{array}{l}\text { Similar to } \\
9975 \text { SCV } \\
\text { (8-Bolt } \\
\text { Flanged } \\
\text { Closure \& } \\
\text { Cone-Seal } \\
\text { Plug ) }\end{array}$ \\
\hline $\begin{array}{l}\text { Containment } \\
\text { Vessel } \\
\text { Closure } \\
\end{array}$ & $\begin{array}{l}\text { Pipe Cap or } \\
\text { Plug }\end{array}$ & $\begin{array}{l}\text { Single Bolt, } \\
\text { Dual O-Ring } \\
\text { Sealed Plug }\end{array}$ & $\begin{array}{l}\text { Multi-Bolt } \\
\text { Dual O-Ring } \\
\text { Sealed Plug }\end{array}$ \\
\hline Shielding & Optional & $\begin{array}{l}\text { Payload } \\
\text { Basket }\end{array}$ & Optional \\
\hline $\begin{array}{l}\text { Crush Test } \\
{[10 \text { CFR } 71.7} \\
3(c)(2)]\end{array}$ & $\begin{array}{l}\text { Not } \\
\text { Required } \\
\text { Due to } \\
\text { High } \\
\text { Package } \\
\text { Density } \\
\end{array}$ & $\begin{array}{l}\text { Required: } \\
\text { Overpack } \\
\text { Will Protect } \\
\text { CV Integrity }\end{array}$ & $\begin{array}{l}\text { Not } \\
\text { Required: } \\
\text { Overpack } \\
\text { Will Protect } \\
\text { CV Integrity }\end{array}$ \\
\hline $\begin{array}{l}\text { Decay Heat } \\
\text { (Watts) }\end{array}$ & 10 & $>10$ & 20 \\
\hline $\begin{array}{l}\text { Radioactive } \\
\text { Contents }\end{array}$ & $\begin{array}{l}\text { Table V } \\
\text { (49 CFR } \\
\text { 173.417): } \\
\text { Scrub } \\
\text { Metal } \\
\text { Alloy, Pu } \\
\text { Metal, \& } \\
\text { Pu Metal } \\
\text { Alloy }\end{array}$ & $\begin{array}{l}\text { Pu and/or U } \\
\text { Metal and } \\
\text { Oxides per } \\
\text { Tables } 1.14 \\
\& 1.15 \text { of } \\
9975 \text { SARP, } \\
\text { and Table V. }\end{array}$ & $\begin{array}{l}\text { Pu and/or U } \\
\text { Metal and } \\
\text { Oxides per } \\
\text { Tables } 1.14 \\
\& 1.15 \text { of } \\
9975 \text { SARP, } \\
\text { and Table V. }\end{array}$ \\
\hline
\end{tabular}




\section{Judging and Evaluation}

Both design proposals satisfied the packaging performance requirements given in Section II. However, the two designs teams followed very different paths to this common goal and thereby, have emphasized different aspects of the design process.

To ensure an independent evaluation of the design proposals, several uninvolved but interested individuals from the DOE packaging community were invited to serve as judges. The judges and other interested individuals received presentations from the two team leaders, and the judges weighed the merits of the designs relative to the evaluation criteria established for the competition. The winning design was determined simply by the highest total from the five evaluation categories.

As expected, the competition generated considerable discussion within the packaging community about the overall issue of timely replacement of the $6 \mathrm{M}$ and who has the resources to support the activity.

\section{Conclusions and Recommendations}

The limited scope of the SRS internal design competition provided a cost-effective means of developing two independent and practical proposals for the developing a new GPFP design. The competition process was funded just enough to enable the feasibility of competing concepts to be pursued to the point of demonstration and evaluation by potential users. Ultimately, the best aspects of the two design proposals will be incorporated into a final design proposal for development of the GPFP. That process is underway at the time of this writing

In summary, the internal design competition proved to be a very cost effective method of addressing a complex task that by its nature includes competing priorities. In addition, the technique is general in nature and can be applied to virtually all engineering design processes.

\section{References}

1 York, A. R. and Gruda, J. D., Crush and Impact Analysis of the AT-400A, SAND97-0119, Sandia National Laboratory, March 1997 